\title{
Nick Name as a Mind Pattern Disclosure of the Minangkabaunese Community in Pariaman, West Sumatera
}

\author{
Ermanto \\ Faculty of Languages and Arts \\ Universitas Negeri Padang \\ Padang, Indonesia \\ e-mail: ermanto@fbs.unp.ac.id
}

\begin{abstract}
The purpose of this study is to express the lingual form and value of the positive and negative sense of the nickname of coastal communities in Pariaman, West Sumatra, Indonesia. The nickname is a lingual form used to refer to the physical and psychic existence of a given person. The issue of a nickname relates not only to the matter of the linguistic structure but also to the motivation of name selection, the aspects affecting the choice of names, the use in the life of society, the logic of thinking and the cultural behavior of the people in their selection and use. The nickname is a form of the name of self that is generally the name of the giving by the community to a person. This research data is nickname (nickname) of coastal Minangkabau community in Pariaman. The research informant was determined by snowball sampling technique. The stages of data analysis are (1) identification of nickname data based on the pattern of its formation, its reference, and the sense of positive-negative value, (2) the nickname classification based on the three research objectives, (3) nickname interpretation, and (4) inference. The research findings are nicknames (nicknames) consisting of two lingual forms namely (1) word-shaped and (2) phrase-shaped. The dominant nicknames are nicknames that have negative taste values such as Bulek, Baluik, Bontot, Ceke, Subuah, Karumuik, Piak Gulo, Am Jawi, Adit Juliang and few of which are of positive or neutral taste. Giving a nickname that is worth a negative taste to someone is one form of verbal violence committed by the community. Instead, giving and using negative nicknames should be eliminated in the life of the Minangkabau community.
\end{abstract}

Keywords - nickname, taste value, negative, Minangkabau

\section{INTRODUCTION}

The name is a lingual unit form of a lexical unit created and used by the language speakers concerned to determine the entity of something like people, places, and other material things. From a linguistic perspective, a name is a word (or phrase) for calling or calling people (places, things, animals, etc.) and the name also means the title, designation (Center for Development and Language Development, 1997: 681). Crystal (1987: 112) more specifically states that a name is a word or phrase that identifies a person, place or specific objects because an entity is an individual rather than a class member. Thus, the name is a lingual form of a word or phrase formed and used by its speaker to mention a specific entity. The name can be to define the entity of a person, place, objects, institution of a specific nature. Given the name created and given to the entity, it will be easily distinguished from the other entity so that the entity becomes more specific.

The name is not only used to determine the entity of the person but also to determine the place entity, and other objects. Linguistically, the study of names as linguistic studies primarily focuses on the study of people's names and the study of place names. Science studies the names by Crystal (1987: 112) referred to as onomastics. Science studies of these names are usually divided into: (1) the study of persons names (personal) called anthroponomastics and (2) the study of place names called toponomastics Crystal (1987: 112). Based on this, the focus of name studies in linguistic research is the study of people's names and the study of place names.

The nickname in this study is part of the name of the self. The name of self is a form of language used to refer to the existence of a whole body of a given body. The whole physical and psychic that unite forms the person collected or replaced by the name of the self. If calling a person's name means the whole person's physical and psychical intent. This means that the name of self is essentially very urgent in human beings and very urgent in human life.

With regard to the urgency of the name of self and human life, many primitive societies do not like to hear their names being used and they believe that the whole of existence lies in its name and they-in that way-are exposed to other influences (Crystal, 1987: 9). This belief will have an impact on the use of names in the life of the language community in accordance with the culture of that society.

The study of names in different cultures of the world is described below. First, Zaitzow, Skipper \& Bryant (1997: 45) have said that an investigation of nicknaming among 113 female prisoners showed that nearly two-thirds of the women had a nickname; the nicknames were almost always accorded by family or peer group members, referred to physical or behavioral characteristics or were variations of given names, and were rarely negative; these findings differ sharply from earlier reports of nicknames of male criminals and male inmates. 
Second, Butkus (1999: 125) has said that the nicknames of Lithuanian country people are investigated in order to determine the motivations for creating the nicknames and to develop a system of nickname classification based upon the motivations; more than 15,000 nicknames are included in this study and ten categories of nicknames are discussed; the category of nicknames referring to one's physical features accounts for nearly one third of all nicknames.

Third, Haggan (2008) has said that although nicknaming among teenagers and nicknaming among Arab adults has been studied, nicknaming among Arab teenagers has not; nicknames of their peers were collected from Kuwaiti teenagers, and Kuwaiti undergraduates judged the nicknames as derogatory, affectionate or neutral; in spite of religious injunctions against the practice, hurtful nicknames were the most common and females were as likely as males to receive uncomplimentary nicknames; nicknames were also classified as based on appearance or on personality/behaviors, and how they reflected local or western culture.

Fourth, Adams (2008: 206) has said that George W. Bush freely assigns nicknames to political aides, cabinet secretaries, legislators, reporters, and others who cross his presidential path; nicknaming seems an innocuous, playful social behavior, but it is a more complex onomastic maneuvre than it seems, and more significant: it is a species of Althusserian interpellation, a means of 'hailing' actors within the state and converting them into subjects of state ideology, which, on one construction (the one operating here), collapses state authority and the executive power of the American presidency.

Fifth, Adam (2009:81) has said that nicknames distribute power within a social group: they can be imposed, or they can be used by agreement between namer and named; this is not the difference between political and apolitical uses of nicknames: agreement is a political act, the result of social negotiation, in which the nickname is a token.

Sixth, Leslie \& Skipper (2009:273) have said that to develop a form of analysis for nicknames and nicknaming, we propose a theoretical construct, using our empirical knowledge of nicknames, and posit a uniquely sociological perspective that describes and explains nicknames as aspects of the process of social action. Our approach is couched in terms of a theory of naming potentially useful to all scholars of names, whether they study human nicknames, the names of post offices in Kentucky, pet names of body parts, or the religious toponymsof Guatemala.

Seventh, Black, Wilcox \& Platt (2014:127) have said that nicknames can be friendly, showing peer approval and in-group unity; they can also be cruel and vicious; nicknames can be bestowed due to appearance, personality, preferences, background, or experience; they are also used for in-group communication about hidden activities or identities.

Eighth, Babane \& Chauke (2015) have said that the aim of this paper is to discuss the meaning and relevance of the nicknames given to soccer players in the Premier Soccer League in South Africa, either as a token of appreciation or disapproval; the argument raised in this paper is that there is a marked deterioration in the creative naming of nicknames in the contemporary dispensation unlike in the past; the result shows that soccer stars are given nicknames either by coaches, teammates or by fans and these players are famously known by their nicknames, rather than their personal first names.

Ninth, Chauke (2016:378) has said that vatsonga have the tendency of giving nicknames, which act as tokens of appreciation or disapproval; nicknames are one of the forms of address, which Vatsonga as a nation uses to either praise or show disapproval of a person's behavior; amongst Vatsonga, in informal situations, first names are often used interchangeably with nicknames.

Tenth, Mensah (2016:184) has said that nicknames individuate and identify their bearers and stand out with more sociocognitive forces than the conventional names within the socio-cultural setting and beyond; he was examined the sociolinguistic and ethnographic significance of nicknaming among female adolescents in Nigeria with particular emphasis on those living in Calabar Metropolis, Cross River State, south-east Nigeria; he was concluded that female nicknames are creative, cultural symbols and styles by means of which female adolescents express themselves as a form of critical resistance to the stereotypical image of women in a conservative society, given their psychological, sexual and aesthetic appeal.

Later, the name in the life of the Minangkabau community also has a unique phenomenon. In general, Minangkabau people are also accustomed to give names that have a negative and positive meaning to someone. Thus, it is necessary to conduct research on the name of the Minangkabau community from the socio-cultural aspect.

The name of self in a society can not be viewed as a simple matter of language. The name will give a specific identity to the personal identity in totality of the physical and psychic. Therefore, in the life of society, the question of self-identity is not only related to the matter of language structure and the meaning of the name of the self, but also related to the motivation of name selection, the aspects that influence the name selection, its use in community life, the logic of thinking and cultural behavior of the community in the election and its use.

Crystal (1987: 9) raises some names of issues that intersect with the mindset and cultural behavior of society as in the tribes of the world. According to Crystal (1987: 9), the famous things in a tribe like Australia and New Zealand are two names: (1) public names for general use; (2) a secret name known only to God and close members of his group. In addition, Crystal (1987: 9) also explains that the Todas community in South India does not like their name utterances, if they are asked for their names they will say something else and there are people who believe that death can have a taboo effect on the use of a name. Often the names of dead people are not spoken. This thought may be more because of anxiety than respect for the dead. It is believed to be the death of someone then the name's utterance will bring misfortune and death on him. Crystal (1987: 9) also explains that in some cultures such as Polynesian, when a person dies, another society whose name must change its name or if it is related to a word in 
its name, the word of the name must be replaced. In fact, if a child dies, the same name will be called with some evil name to show the spirit of death.

Regarding the existence of names in various cultures of the world as described above, the use of names in the life of the Minangkabau community also has a unique cultural phenomenon. Generally, Minangkabau children forbid and will be angry if his father or mother's name is mentioned in front of him. In addition, Minangkabau people are also accustomed to give a nickname that means negative or weaknesses against someone other than give a nickname that means positive. Thus, the selfstudy of the Minangkabau community and its use from the socio-cultural aspect should receive attention.

The study about the self-esteem of Minangkabau society needs to be done because it departs from the reality of the very diverse forms of the name of the self owned by the community. In the life of Minangkabau society, the philosophy of life related to self-identity is expressed in the expression "ketek banamo, gadang bagala". That is, when a little called the name, after the big called the title (custom). If it departs from the culture philosophy, the Minangkabau people should only have two forms of the name themselves (1) the original name of the parent and (2) the title of culture. The original name is the name given by parents as a child and is used as a formal name for any activity ranging from formal names in schools, identities, official letters. The title of culture is the name given by the big family (especially the role of uncle) usually just before the wedding ceremony. That is, the title of culture is the name obtained for those already grown (married).

The reality in the life of Minangkabau society, the individual not only has two forms of names that should apply according to the life philosophy embraced the Minangkabau society. In addition to the two forms of the name, in the community also appears other forms of self-identity that is (1) the nickname of giving a friend or another person, (2) the name of the pitch or the parents' favorite name, and (3) the name of the greeting. The nickname of a friend or other person is a name given by a friend or another person either as a child or given after a big one. The name of the pitch is the name given specifically by a parent or family to someone to show affection. The name of the greeting is the short name used to greet which usually comes from the original name. Thus, in Minangkabau society it will be possible to simultaneously possess all five forms of the name, or to have only four forms of names, or to have only three forms of names, or to have only two forms of names, or to have only one form of name dependent upon strict rules Minangkabau customs in the area. In the study, it was reviewed the name of Minangkabau coastal community in Pariaman.

Seen from a linguistic standpoint, the self is a lingual form of words or phrases. When viewed from the standpoint of the word class, the name belongs to the noun or noun class (Jackson, 1996: 52). According to Kridalaksana (1990: 6) the name of self belongs to the noun persona group and the syntactic character of the noun persona can be substituted by the word he, he, them and can be preceded by the si particle. Therefore it can be said that a good name consisting of a word or consisting of several words is a class of nouns or noun phrases.

The name of self will refer to the person figure because that is the class of noun or noun phrases. As the noun word noun or noun phrase, then the name of self is the word that gives shadow and refers to the visual person's physical figure. The word type of name lies in the fourth place in the hierarchy of justice as suggested by Sudaryanto (1997: 292) and the hierarchy of the word (starting from the highest, the abstract and the less empirical) are: (1) the word term, (2) ) said the bearer of wishful thinking, (4) the word name, (5) the word onomatopoeia. The word term is a combination of sound with the concept, ordinary word is a combination of sounds with meaning, the word imaginary is an ordinary word that contains shadows or images of a mental nature, said the name is a word of conjuration that also contains a perception or visual perception, and the word onomatopoeia is the name of the word that contains the voices of sound. Seen from several viewpoints of the level of reason, class of words and hierarchy of power, it is clear that the name of self is part of the study of language.

As the lingual form of the word, the name of self can be seen from several linguistic theories such as morpheme theory, words, and phrases. To examine the names of these Minangkabau people, the morpheme, words and phrases used by Jackson (1996: 1-16), Matthews (1974: 20-36; 77-96), Bauer (1983: 7-32), Nida (1949: 78-85), Katamba (1993: 17-54).

According to Sudaryanto (1997: 294) said the name is very strongly bound to use in certain places and at certain times. That is, one can say something as a word of a name when the word in question always shows a certain self or a certain figure and at the same time tells the identity of a person or the person at the time the word is used to call it. Therefore, the name of self is unfeasible and often impossible to translate, except only occasionally adjusted the sound and its formal form in certain languages such as Johanes can be Johan, Johan, or John and Maria can be Mary, Maryam, or Miryam; but Yayah, Mursiyem, Dalimin, Simatupang did not become another form (Sudaryanto, 1997: 295).

The name as a form of speech clearly has a referent to a certain figure. Therefore, the name certainly has a certain thought, purpose or meaning. Widodo (2001: 161) concludes that the meaning of Javanese self-identity can be traced to several things: (1) the basis of the election, (2) meaning and reference, (3) denotation and connotation, (4) meaning and usage, (5) synonymy in the name of self. Starting from the description of the various backgrounds of the self-election of the people above, it can be concluded that the background of self-naming will intersect with four main dimensions of adat, modern, traditional belief / habit and religion. If viewed the background of the naming of Minangkabau society then the dimension of religion is the religion of Islam.

The four main dimensions affecting the self-selection of the community are described below. Custom dimension usually influences in the selection of the name of self. Title names of culture such as in Minangkabau or the necessity of a clan name in the name of self as in Batak is a form of influencing custom dimension. Modern dimension also influences, especially the 
knowledge and education knowledge that parents have on the outside world of their culture. The form of self-titling in many ethnic groups in Indonesia that is compatible with the name of the people of Europe or America, for example, is a form of modern dimensional influence. The effect of traditional belief / habit dimension is seen in self-giving which should look at the day and time of birth, place of birth, events or events occurring around birth. This may be the case in traditional Javanese society. The religious dimension also influences the self-giving of the people. The name babtis in the name of the Christian community is a form of influence of the religious dimension, as well as the name of the Muslim community which is heavily influenced by the names taken in the Qur'an.

In fact, the nickname used by the coastal Minangkabau community in Pariaman many have negative taste values. Giving a nickname that is worth a negative taste or which is often also called the name of a negative nickname can be said as a form of verbal violence committed by ethnic Minangkabau community to the members of the community. Choirunnisa (in Fitriana, Pratiwi, and Suanto, 2015: 81) states that one form of violence is verbal or violent violence perpetrated (in the form of) painful words; these painful words usually mean abusing a child's abilities, assuming the child as a source of misfortune, minimizing the child's meaning, giving a negative nickname to the child, and suggesting that the child is not expected to have a long-term impact on feelings and may affect their self-image.

In fact, nicknames that are either negative or often called negative nicknames often begin in households that may be started by family members and are followed by community members. Fitriana, Pratiwi, and Suanto (2015: 91) stated that the results of the research note that parents experience greatly affect the environment of parents in verbal violence against preschoolers; parents who have good experience have behaviors that are less likely to engage in verbal abuse in their children, but rather parents who have bad experiences tend to abuse verbal abuse in their children.

In addition, it can also happen otherwise, giving a nickname that is worth a negative taste or which is often also called a negative nickname is often also started from members of the community and followed by family members. Community groups sometimes occasionally initiate verbal abuse against a member of the community. Related to this matter can be seen from the conclusion of research of Simbolon (2012: 237) that forms of bullying ever happened in dormitory of University A that is in the form of intimidation, logging, beating, dirty utterance, and harassment; intimidation is done by using harsh words or so-called bullying verbal.

Other research on verbal violence is also common in many people's lives. For example, in the comedy program Pesbukers, which is ANTV's flagship comedy program, there are 1,396 occurrences of verbal violence scenes; this happens because people sometimes do not realize that what is done is violence because it considers it as usual and merely a joke; other than that expressed a lot of verbal violence that tends to insult and degrade others (Putra, 2015: 292).

Starting from the description above, research matters relating to the name of the Minangkabau community themselves, the reason why this research is important. This research is expected to reveal the phenomenon of nickname in language and its relation with mindset and cultural behavior of Minangkabau society more complete and deep.

\section{METHOD}

The type of this research is qualitative descriptive research that describes the name of self, especially the nickname of Minangkabau community in Pariaman. The data of this research is the nickname of Minangkabau community along with the context of its use in Pariaman. Sources of data used are oral sources of speech from informants in the life of the Minangkabau community in Pariaman. The research informant was determined by snowball sampling technique. Methods and techniques of data collection used is a method of proficiency with basic techniques and advanced techniques and methods refer to basic techniques and advanced techniques. The research data collected using technically competent method followed by fishing technique, recording technique and record technique. The research data collected using technical method is continued with the technique of tapping with advanced technique is the technique of free libat captive and recording technique. Data analysis is performed by the following stages: (1) identification of nickname data based on the pattern of its formation, its reference, and the sense of positive-negative value, (2) the nickname classification based on the three research objectives, (3) nickname interpretation, and (4) ) inference.

\section{FINDING AND DISCUSSION}

The Minangkabau Coastal Society of Pariaman in addition to having a real name (formal name) also has a nickname (nickname). Based on the results of interviews with the community can be disclosed the reason of giving a nickname in the life of Minangkabau Coastal Society in Pariaman. The reason for nicknames that have negative, positive and neutral meanings in the life of the Minangkabau Coastal community in Pariaman are (1) the habit of using a nickname because there may be the same person's name, (2) the custom of the community member to distinguish the person from the other, (3) the habits of community members to respect the person, (4) the customs of the community members to create entertainment, (5) the habit as a marker of intimacy in the community, (6) the habits of community members to facilitate people to know the person, (7) (9) the habits of community members to facilitate the recognition of a person, (10) the habits of community members to facilitate the recall or marking of a person by virtue of his nature. 
Generally in the life of the Minangkabau ethnic community of Coastal Society in Pariaman, the nickname given to a member of society is a negative nickname with reference to something negative such as Bulek, Baluik, Bontot, Ceke, Subuah, Karumuik, Piak Gulo, Am Jawi, Adit Juliang, Mak Itam Tanjuang, Oncu Pasik, Ajo Lauak, Agung Sibu, An Subuah, Andeh Etek, and Santi Jambatan and a small portion are given a nickname with reference to something positive or neutral like Bulek, Inggih, Adang, Amoi, Muncak, Ongga, Piak Manih, Yani Pelo, Ajo Datuak, Andah Milah, Ujang Doyok, Piak India, Jakar Sawah, Ajo Mane, Anaih Muncak, Ap Bengke, Inyiak Japang, Amur Tanjuang, and Ali Padang.

Based on the lingual facet review, the nickname of the Minangkabau Coastal Society in Pariaman consists of two lingual forms (1) nicknames in the form of words and (2) nicknames in the form of phrases. Based on a review of the pattern of formation, the nickname of the Minangkabau Coastal Society in Pariaman consists of sixteen (16) following patterns: (1) pattern of formation 1: name (word form), (2) pattern of formation 2: name + (3) pattern of formation 3: name + father (phrase form), (4) pattern of formation 4: name + aspiration (phrase form), (5) pattern of formation 5: name + brother (form of phrase), (6) pattern of formation 6: name + similarity (phrase form), (7) pattern of formation 7: name + ownership (form of phrase), (8) pattern of formation 8: name + physical condition (phrase form) (10) pattern of formation 10: name + psychic condition (phrase shaped), (11) pattern of formation 11: name + work (phrase form), (9) (12) pattern formation 12: name + behavior (phrase form), (13) pattern formation 13: name + event (phrase form), (14) pattern titan 14: name + status (phrase form), (15) pattern formation 15: name + tribe (phrase shaped), (16) pattern 16: name + place / origin (phrase-shaped).

A word-shaped nickname consists of a pattern of names with six reference formations such as physical condition, likeness, status, psychic condition, events, and behavior. The phrase-shaped nickname consists of fifteen patterns of names with fifteen references to their formation as opposed to physical conditions, fathers, ideals, siblings, likenesses, possessions, physical conditions, physical and tribal conditions, psychic conditions, occupations, attitudes, , status, tribe, place / origin.

The Minangkabau Coastal Society in Pariaman has a nickname consisting of two forms, word-shaped and phrase-shaped. First, the nickname is a lingual word. Based on examples of nicknames in the form of words used by the ethnic Minangkabau Coastal community in Pariaman, in general the nickname has a negative sense value that is (1) nickname with reference to physical condition has negative taste value, (2) nickname with reference likeness has (4) nickname with reference to a psychic condition having negative taste value, (5) nickname with event reference having negative taste value, (6) nickname with referral behavior has negative taste value.

A nickname in the form of word lingual by using physical condition which has negative taste value that exist in the life of Minangkabau Coastal community in Pariaman is as follows: Bulek, Buncik, Buncilak, Duyun, Jangguik, Tempang, Apuak, Bangkok, Boncel, Bosong, Cangkuak, Capuak, Cebol, Ceper, Enek (kecil), Gagok, Gambuang, Ganduik, Gembul, Kalek, Kaliang, Kapsul, Karisma, Kesuik, Kicik, Kribo, Kusuik (kusut), Kutilang, Lambuak, Langeh, Langiah, Lepai, Lesuik, Montong (putus), Sela, Semok, Teloh, Tengkuih, Tenjak, and Pitok. Some examples of nicknames of word-shaped lingual names by using similarities of negative taste value that exist in the life of ethnic Minangkabau coastal communities in Pariaman are as follows: Ateng, Baluik, Godok, Japang, Kabayan, Kancie, Kingkong, Koko, Kundue (labu), and Kunik (kunyit).

An example of a nickname in the form of a word lingual by using negative psychic conditions contained in the life of ethnic Minangkabau ethnic group Pariaman as such as Ceke which means is 'People who stingy'. An example of a nickname that is in the form of a word lingual by using negative events contained in the life of the Minangkabau ethnic group of Overseas Pariaman as such as Subuah which is meant 'People born at dawn'; Nepon is meant to be 'The one who was born during the Japanese colonial era, that is when there was a Japanese Nipon'. Some examples of nicknames in the form of lingual words using negative behavior contained in the life of ethnic Minangkabau in Pariaman namely Karumuik, Katorok, Kutar, Lebe, Lembang, Lentok, Letoy, Malanca. Nicknames in the form of words with reference to negative behaviors such as Karumuik are meant to be 'sulky'; Katorok is meant to be 'gossiping'; Kutar is meant as 'The person who is not polite'; Lebe was meant to be 'the one who cried'; Lembang is meant to be 'People who love crackers of the valley'; Lentok is meant to be 'People who like to walk casually'.

Based on the research findings, only a few examples of nickname names that have positive or neutral sense values are (1) nicknames with physical condition references having positive taste and neutral taste values; (2) nicknames with similarity references have taste value positive, (3) the nickname with the status reference has a positive taste value and a neutral value.

Second, the nickname is a lingual phrase. Based on examples of nicknames in the form of words used in the life of ethnic Minangkabau ethnic Coastal Communities in Pariaman, in general, the nickname also has a negative sense of the name that is (1) nickname in the form of lingual phrase with pattern name + similarity has a sense value negative, (2) nickname-shaped lingual phrase with pattern name + possession has negative taste value, (3) nickname in lingual phrase with name pattern + physical condition has negative taste value, (4) nickname in lingual form of phrase with the name pattern + physical condition + the tribe has negative taste value, (5) the nickname in the form of lingual phrase with the name pattern + the psychic condition has negative taste value, (6) nickname phrase lingual phrase with pattern name + work has taste value negative, (7) nickname-shaped lingual phrases with a name + behavior pattern have a negative sense value $f$, (8) nickname-shaped lingual phrase with name + event pattern has negative taste value, (9) nickname in lingual phrase with name + status pattern has negative taste value, (10) nickname in lingual form phrase with pattern name + place / origin has negative taste value.

Based on the research findings, the phrase-shaped nickname in the form of a combination of the name of self with the similarity of negative taste value is as follows: Piak Gulo, Idil Unyil, Piak Saka, Piak Talua, Sii Ateng, Ujang Ameh, Ujang 
Gampo, Yuang Asok, Yuang Kabau, dan Yun Fuso. The phrase-shaped nickname in the form of a self-named name with a negative value of ownership is as follows:Am Jawi, Edi Sawah, Eni Kandang, Etek Kadai, Maih Jaguang, Men Kadai, Piak Padi, Ros Lapau, Upik Ampera, Uwan Kijang, Yuang Ambia, dan Agus Jawi. The ethnic Minangkabau Coastal community in Pariaman often gives a nickname to the members of the community in the form of lingual phrases in the form of a person's name combined with a person's negative physical condition is as follows: Af Sula, Aguh Tuneh Aji Ompong, Aji Tando, Ajit Laweh, Ajo Apuak, Ajo Botak, Ajo Colak, Ajo Itam, Ajo Tando, Ajo Tangkurak, Ajo Timbua, Alif Tangan Sabaleh, Amak Tando, Amin Colak, Andi Ompong, Andi Pengka, Anduang Kijok, Angah Tenjak, Anih Laweh, Anton Botak, Anyih Pendek, Ardi Boneang, Ardi Pendek, Atik Cik Mato, Baiti Tempang, Budi Kopok, Budi Lepai, Budi Tengkak, Bujang Abun, Bujang Gadang Godok, Bujang Gerai, Bujang Sumbiang, Buyuang Abun, Buyuang Aluih, Buyuang Bisu, Buyuang Bulek, Buyuang Bungkuak, Buyuang Celek, Buyuang Cilak, Buyuang Gagok,Buyuang Kaliang, Buyuang Karuik, Buyuang Kurok, Buyuang Laweh, Buyuang Leo, Buyuang Panjang, Buyuang Penyek, Buyuang Sela, Buyuang Tando, Buyuang Tanggiang, Buyuang Uban, Cik Andah, Cik Uniang, Dawin Sulah, Dina lesuik, Dodi Teleang, Doni Capuak, Edi Gapuak, Ela Bigen, Elsa Tonggeang, Em Itam, Ema bangkok, En Gapuak, Eni Cilalek, Era bulek, Fika Kaliang, Ida Botok, Ida Cilalek, Idun Bengkeang, In Kurok, Ipan Kaliang, Isan Kompoang, Isil Laweh, Itam Baro, Itam Kaliang, dan Iwan Jangguik. In addition, the ethnic Minangkabau Coastal community in Pariaman also gives a nickname to the members of the community in the form of a lingual phrase in the form of a person's name with the psychic condition and negative taste value as follows:Oncu Pasik, Oni Tenggen, Buyuang Ongeh, Buyuang Pandia, Buyuang Sawan, Eli Ceke, Man Saraf, Udin Tea, Upiak Tenggen, Yuang Tea, Yuang Tengak, dan Zal Gilo. The ethnic Minangkabau Coastal community in Pariaman also gives a nickname to the members of the community in the form of a lingual phrase in the form of a person's name with a job with a negative taste value as follows: Ajo Lauak, Ajo Sate, Am Bendi, Am Kambia, Bet Lontong, Buyuang Buruang, Buyuang Talua, En Maliang, Bujang Taranak, Doyong Cukua, Em Jaguang, Emi Lado, Emi Sala, Imaih Sala, Imar Jaguang, Imar Lompoang, Imiang Lontong, Is Kue, Ita Talua, Juih Lompong, Jup Becak, Kai Lado, Kar Lado, Linda Umang-umang, Mael Ampas, Mak Ajo Sate, Mar Godok, Muih Lompong, Piak Lontong, Piak Ayam, Piak Seken, Piak Talua, Saril Kumpu, Sawir Galon, Semi Sayuah, Sijaih Mangkuak, Sijaih Sala, Sijuih Tempe, Sita Ayam, Ujang Kasiak, Ujang Maco, Ujang Pupuak, Ujang Talua, Uniang Talua Asin, Upik Cubadak, Upik Jawi, Upik Pical, Upik Sala, Upik Talua, dan War Tukang.

Based on the findings of the researcher, only a small number of examples of nicknames have been found that have positive or neutral sense values (1) nickname-shaped lingual phrases with a father + name pattern have neutral sense values, (2) nicknames in the form lingual phrase with name + aspect pattern has positive taste value, (3) nickname in the form of lingual phrase with surname + surname has positive taste value; (4) nickname of lingual phrase with pattern name + likeness has taste value (5) nickname in the form of lingual phrase with pattern name + possession has neutral taste value, (6) nickname in the form of lingual phrase with name pattern + physical condition has positive taste value and has taste value neutral, (7) nickname-shaped lingual phrases with the name + job pattern has a positive taste value and has a race value a neutral nickname, (8) a nickname in the form of a lingual phrase with the name + event pattern has a neutral sense value, (9) a nickname of a lingual phrase with a name + status pattern has a positive sense value and has a value, (10) lingual-shaped phrase with pattern name + tribe has positive taste value, (11) nickname in the form of lingual phrase with pattern name + place / origin has neutral taste value.

Based on the results of interviews with members of the community can be disclosed the purpose of giving a nickname in the life of Minangkabau Coastal Society in Pariaman who intend negative. The purpose of giving a negative-meaning nickname is (1) to awaken the person from his or her bad behavior, (2) to insinuate a bad person, (3) to change his bad attitude for the better, (4) to advise a person who behaves badly (6) to reprimand someone according to his or her bad behavior, (7) to inform that there is a deficiency in the person given the title, (8) to deride a person by virtue of his / (9) to stigmatize a person in the presence of a deficiency, (10) to express a person according to his or her bad habit, (11) to give a reprimand to the owner of the call if related to his or her bad habits.

Similarly, based on the results of interviews with members of the community can be disclosed the purpose of giving a nickname in the life of Minangkabau Coastal community in Pariaman who intend positive. The purpose of giving a positivemeaning nickname is (1) to create a closer, closer atmosphere, (2) to respect / respect someone, (3) to motivate in order to maintain a good attitude from someone, (4) to be a role model for others (5) to praise the called person, (6) to facilitate recognition of one's goodness, 7) to respect the person according to his or her own merits, (8) to inform the public about the characteristics or the good / positive nature of the self that person.

What is the so-called / invoked response / reaction with that negative negative nickname? Based on the results of interviews with members of the community can be expressed the reaction of people who are given a nickname in the life of the Minangkabau Coastal community in Pariaman who intend negative. The reaction of community members who are given a negative calling name is (1) they express anger, (2) they express discomfort, (3) they feel embarrassed and insecure, (4) they disagree with the call, (5) protest, (6) they claim to reply also with negative nicknames, (7) they declare not accept, (8) they are indifferent when others call him by that nickname, (9) they are resigned.

What is the so-called / invoked response / reaction with that negative negative nickname? Based on the results of interviews with members of the community can be expressed the reaction of people who are given a nickname in the life of the Minangkabau Coastal community in Pariaman who intend negative. The reaction of community members who are given a negative calling name is (1) they express anger, (2) they express discomfort, (3) they feel embarrassed and insecure, (4) they disagree with the call, (5) 
protest, (6) they claim to reply also with negative nicknames, (7) they declare not accept, (8) they are indifferent when others call him by that nickname, (9) they are resigned.

\section{CONCLUSION AND RECOMMENDATION}

Coastal Minangkabau ethnic community in Pariaman in its communication life besides having real name (formal name) also many have nickname. Based on the results of the interview, the reasons for giving a nickname that has negative, positive and neutral meanings are (1) the habit of using a nickname because there may be the same person's name, (2) the custom of the community member to distinguish the person from another, (3) (4) the habits of community members to create entertainment, (5) customs as a marker of intimacy in the community, (6) the habits of community members to make it easier for people to know the person, (7) the habits of community members indicate the status (9) the habits of community members make it easier to recognize a person, (10) the habits of community members make it easier to remember or mark someone by their nature.

Based on the lingual facet review, the Minangkabau coastal society in Pariaman consists of two lingual forms (1) nicknames in the form of words and (2) nicknames in the form of phrases consisting of sixteen. A word-shaped nickname consists of a pattern of names with six reference formations such as physical condition, likeness, status, psychic condition, events, and behavior. The phrase-shaped nickname consists of fifteen patterns of names with fifteen references to their formation as opposed to physical conditions, fathers, ideals, siblings, likenesses, possessions, physical conditions, physical and tribal conditions, psychic conditions, work, status, tribe, place / origin.

Based on the results of interviews with members of the community it may be possible to (1) to awaken the person from his misbehavior, (2) to insult the bad man, (3) to change his bad attitude to be better, (4) to advise a person who behaves badly, (5) to create a sense of shame for his bad behavior, (6) to reprimand someone according to his bad behavior, (7) to inform that there is a deficiency in the person given the title. ) to deride a person by virtue of his / her own traits so that the person concerned may change, (9) to pledge a person in the presence of a deficiency, (10) to express a person according to his or her bad habit, (11) to give a reprimand to the owner of the call if related to the custom bad.

Based on the results of interviews with members of the community can be expressed the reaction of people who are given a nickname in the life of Minangkabau coastal society in Pariaman people who mean negative. The reaction of community members who are given a negative calling name is (1) they express anger, (2) they express discomfort, (3) they feel embarrassed and insecure, (4) they disagree with the call, (5) protest, (6) they claim to reply also with negative nicknames, (7) they declare not accept, (8) they are indifferent when others call him by that nickname, (9) they are resigned. Giving a nickname that is worth a negative taste or which is often also called the name of a negative nickname can be said as a form of verbal violence committed by ethnic the Minangkabau coastal society community members.

Based on the above conclusion put forward the following suggestions: the Minangkabau Coastal community in Pariaman, it is advisable not to give a negative nickname to the community members because it is a form of verbal violence; not using a nickname that is of negative value to community members because it is a form of verbal violence; do not give a nickname that is worth a negative taste to family members because it is a form of verbal violence; not using a nickname that is worth a negative taste to family members as it is a form of verbal violence.

\section{References}

Adams, M. (2008). Nicknames, interpellation, and Dubya's theory of the state. Names: A Journal of Onomastics, Volume 56, pages 206-220.

Adams, M. (2009). Power, politeness, and the pragmatics of nicknames. Names: A Journal of Onomastics. Volume 57, pages 81—91.

Atmosaputro, S et al. (1983). Study of Java names (Research report). Surakarta: Section of UNS Research Development Project.

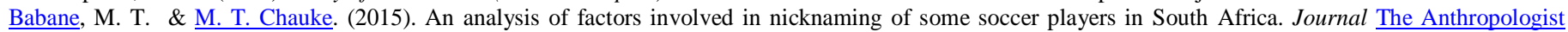
Volume 20 pages $780-787$.

Bauer, L. (1983). English word formation. Cambridge: Cambridge University Press.

Black, S.; Brad W. \& $\underline{\text { Brad P. }}$ (2014). Nicknames in prison: Meaning and manipulation in inmate monikers. Names: A Journal of Onomastics Volume 62 pages $127-136$.

Chauke, M.T. (2016). Nicknaming and nicknames in Xitsonga culture: An onomastic study. Journal of Social Sciences, Volume 49 , pages 378 - 383.

Crystal, D. (1987). The cambridge encyclopedia of language .

Fitriana, Y.; Pratiwi, K. and Suanto, A. V. (2015). Factors associated with parental behavior in verbal abuses against preschoolers. Journal of Psychology Undip. Vol.14 No. April 1, 2015, pages 81-93.

Jackson, H. (1996). Words and their meaning. London and New York:Longman. London:Cambridge University Press.

Leslie, P. L. \& J. K. Skipper. (2009). Toward a theory of nicknames: A case for socio-onomastics. Names: A Journal of Onomastics. Volume 57, pages 273282.

Katamba, F. (1993). Morfology. London: The Macmillan Press.

Kridalaksana, H. (1990). Word class in Indonesian. Jakarta: Gramedia.

Matthews, P.H. (1974). Morphology: An introduction to the theory of word-structure. Cambridge: Cambridge University Press.

Mensah, E. (2016). Female nicknames in Nigeria: The case of Calabar metropolis. Language Matters : Studies in the Languages of Africa, Volume 47, pages $184-202$.

Nida, E. A. (1949). Morphology: The descriptive analysis of words (Second edition). Ann Arbor: The University of Michigan Press.

Language Development and Language Development Center. (1997). Big Indonesian dictionary. Jakarta: Balai Pustaka.

Putra, S. A. 2015. Analysis of verbal abuse content on pesbukers impressions on ANTV". E-Journal of Communication Science. Vol 3 (1), Page 281-294.

Simbolon, M. (2012). Bullying behavior on student dormitory. Journal of Psychology. Volume 39 No. December 2, 2012 , Page 233-243.

Subroto, D. E. (1992). Introduction to structural research methods. Surakarta: Sebelas Maret University Press. 
Sudaryanto. (1993). Methods and miscellaneous techniques language analysis: Introduction to the linguistic research of linguistic culture. Yogyakarta: Duta Wacana University Press.

Sudaryanto. (1997). Linguistics: Essay on language and introduction into language science. Yogyakarta: Gadjah Mada University Press.

Suharna et al. (1987). Self-name system in Java society: Indonesian and local language and literature research projects. Yogyakarta: Depdikbud.

Widodo, S. T.. (2001). Self-name of Java community: Preliminary explorative study of cultural and structural sociology. Thesis not yet published. Surakarta: Sebelas Maret University. 